\title{
Granular Cast Measurement
}

National Cancer Institute

\section{Source}

National Cancer Institute. Granular Cast Measurement. NCI Thesaurus. Code C74768.

The determination of the amount of granular casts present in a urine sample. 